\title{
Principles of Teaching Culture in Basic English Course
}

\author{
QI Jian-tao \\ Ningbo Dahongying University, Ningbo, China
}

\begin{abstract}
In Basic English teaching, cultural teaching is of great importance for cultivating students' awareness and ability of cross-culture communication. In culture teaching, only by following the basic principles, such as interest-driving, cultural equality, induction of differences, practicability and correlation, interactive learning, and so on, can people hope to completely realize the fundamental purpose of culture teaching.
\end{abstract}

Keywords: Basic English teaching, culture teaching, principles

\section{Introduction}

Culture teaching is an important part of Basic English teaching and an important way to improve students' humanistic quality. In Basic English teaching, acculturation can not only enable students to learn the language knowledge, but also enable them to understand social and cultural knowledge; it can also cultivate their English language ability and social and cultural ability. But culture teaching is not just a simple explanation of cultural knowledge. Culture teaching in basic English course, which carries the basic functions of cultural inheritance and cultural comparison, must have appropriateness, pertinence, and scientificity because it concerns the formation of students' cultural values (HU, 1999). Culture teaching can make students understand the culture of target language and enhance their ability of English language in culture learning. If language and culture permeate each other and the two abilities can develop together, the students' ability of intercultural communication could be improved roundly. Through a long-term English teaching practice and reflection, the author thinks that in the process of culture teaching, teachers must adhere to the basic principles: stimulating students' interest, grasping the cultural equality, contrasting cultural differences, the practicability and correlation, good interaction between teachers and students, and so on.

\section{Stimulating Students' Interest in the Target Language Culture}

Interest is the impetus of learning (LIU, 1996). While guiding the students to study the language, it is important to stimulate students' interest in the target language, which puts forward higher requirements for teaching. Teachers must carefully design the process of importing cultural knowledge from textbook knowledge and focus on creating the communicative practice and environment of cultural knowledge of target language. It can put students in a vivid and interesting real context, thus generating their interest in the target language culture and deepening their understanding of cultural knowledge in language practice and situational simulation. Taking

QI Jian-tao, associate professor, master of Endlish language and literature, College of Humanity, Ningbo Dahongying University, Ningbo, China. 
the songs as an example, students can remember the tune and lyrics after listening a few times. But for the text that the teacher arranges to recite, it is rarely done in a short time for them. This fully demonstrates the importance of interest-driving to learning. Teachers should make full use of it and use songs, network videos, and other vivid and interesting technical means to demonstrate English culture during the curriculums which can inspire students' interest and thirst for knowledge of Western culture and enable them to understand deeply the specific cultural forms generated in the specific historical period and the social impact of this cultural form. It cultivates students' interest of learning language and cultural consciousness and broadens their cultural horizons. Accordingly, it can realize the purpose of cultural teaching which integrates cultural teaching into language teaching.

\section{Guiding Students to Grasp the Premise of Cultural Equality}

Another key principle of cultural teaching is to help students establish the basic idea of cultural equality. Every nation has its own culture and every culture has its own characteristics. When studying culture, we should also adhere to the basic principle that no matter how big or small, strong or weak the culture is, there is no good or bad (LIU, 1996). Because English is the language used by most developed countries, it is believed that Western culture is superior, which leads to an exocentric mentality. People should not improperly belittle themselves. Teachers should make students understand that the fundamental purpose of foreign language learning is to successfully achieve cross-cultural communication, to understand and absorb the outstanding elements of other cultures, and finally to make them "work for me". At the same time, foreign language learning should attach importance to its subjectivity. Teachers should learn to use foreign languages more accurately to introduce and disseminate the brilliant national culture, to help students establish the basic concept of cultural equality and language equality and recognize the rationality and advantages of each culture in the process of understanding and learning English language. Let students understand that the process of cultural integration is the process of making up for each other, enriching and completing their own renewal. Learning English means learning English and American culture, but it should not be guided entirely by the orders of Western culture. Teachers should tell students that cross-cultural communication is the dialogue and communication between cultures on the basis of equality.

\section{Paying Attention to the Differences Between Chinese and Western Cultures}

In Basic English teaching, teachers should be good at comparing and summarizing the cultural points encountered in the curriculum. Even some of the cultural differences in daily life can be summarized by teachers first so as to make it easy for students to master the problems that should be paid attention to in the process of cross-cultural communication. Taking the taboo words that spoken with the Anglo-American people when they first met as a case, teachers can summarize as $I, W A R M(\mathrm{I}=$ Income; $\mathrm{W}=$ Weight; $\mathrm{A}=$ Age; $\mathrm{R}=$ Religion; $\mathrm{M}=$ Marriage), Where, Meal. Students can easily communicate with foreign guests just by remembering these words without being embarrassed by a cultural taboo. Because these four words indicate the problems about income, weight, age, religion, marriage, where to go, and whether to eat or not, which should be taken care of in the first meeting with the foreign guests (HAN, 2002). These cultural points should be reasonably distributed in the daily teaching and applied a lot of situational simulation so that the students can practically exercise, be familiar with these differences, and understand the cause of these differences. However, the differences between Chinese and 
British culture are reflected in many aspects. Teachers cannot explain all of these contents in one class and students cannot also solve all the problems about culture in one class. Therefore, the quantity and degree of cultural content are the issues that teachers should deal with flexibly in class. The clever and typical contrast and generalization not only help students master the cultural knowledge easily, but also play a positive role in the improvement of intercultural communication ability.

\section{Paying Attention to the Relevance of Textbook Knowledge and the Practicality of Communication}

The cultural teaching in Basic English teaching should also adhere to two principles: the relevance of textbook knowledge and practical application of communication (HAN, 2002). Culture is a very large concept but cultural teaching is not and cannot be well-rounded. Therefore, all cultural points during the English teaching must be closely related to the textbook and avoid the arbitrary teaching. Then the explanation of cultural knowledge should ensure the practicality of cross-cultural communication. In other words, cultural import should be based on the content of the textbook, and on the other hand, it must take into account the practical needs of students' intercultural communication. On the one hand, it should make students know the differences of English and Chinese language and develop their motivation and interest in English language learning. On the other hand, it can also make students be aware of the differences of English and Chinese culture, thus enhancing cross-cultural sensitivity and cultivating consciously the ability of cross-cultural communication.

\section{Focusing on Forming Good Interaction in Teaching Process}

In Basic English teaching, we should try to cultivate students' sense of English culture and the principle of adhering to interactivity is an effective way to cultivate this cultural consciousness. This interaction is not different from the interaction in classroom teaching. It mainly refers to the interaction between teaching and learning, teachers and students, students and students in cultural teaching. Making this interaction is to realize the multi-level and the all-round communication and communication. The import of culture also includes concepts, cognition, emotion, achievements, and other personal cognitive and subjective aspects (XU, 2000). Through exploration and discussion, people can obtain new findings, reach consensus, and achieve knowledge sharing and common progress. For example, in the article about the Western party, the teacher can ask students to first talk about the form of the Western party in their impressions and the problems about time, manners, speech, and farewells that guests should pay attention to when they are invited to a party.

After supplementing the students' answers and realizing the interaction between teachers and students, the students can be allowed to simulate a Western party if the time is enough. Creating a real language environment, providing cultural atmosphere, and realizing the interaction between students in a group performance can deepen students' understanding of Western culture. Some simple cultural points, such as asking for directions and asking for help, can be carried out in the interaction between teachers and students or students and students. Teachers can use local buildings that are more characteristic to make a situational simulation of asking directions for students. In a word, good interactive teaching plays an important role in the effective import of culture. 


\section{Conclusion}

The cultural import in Basic English teaching raises new questions about language teaching and opens up new ideas. The principle and method of scientific importation are the prerequisite for cultivating students' cross-culture consciousness and the guarantee of the validity of cultural import. In the process of cultural import, it is necessary to make students feel the interest of the target language culture and make them actively participate in the process of cultivating the cross-cultural communication awareness. While helping students to understand British and American culture, it is important to prevent students from forming the wrong values of cultural quality which will lead to blind acceptance and worship of Western culture. At the same time, teachers should pay attention to the generalization and contrast of differences between Chinese and Western cultures, so that students can deepen their understanding of foreign cultures in comparison. In the teaching of culture, the cultural project should be closely followed by the textbook design and should also take into account the cultivation of cultural awareness to improve the practicability of intercultural communication competence. In the course teaching, the teacher should design scientific and vivid teaching process and form a good classroom interaction, so that the students can deepen the understanding of culture through their interactions with teachers and classmates. In the end, people can achieve the purpose of promoting the ability about cross-cultural communication. In conclusion, the cultural teaching during the Basic English teaching is related to the success of studying language and culture for students. Only after teachers summarize the practice experience of teaching and adhere to the principle of scientific teaching can students improve together their language and cultural ability in a coordinated and orderly manner. Ultimately, it can realize the fundamental goal of Basic English teaching.

\section{References}

HAN, X. L. (2002). A combination of culture teaching and language teaching-My view on the foreign language teaching reform. Foreign Languages and Their Teaching, 12, 29-30.

HU, W. Z. (1999). A highlight of cross-culture communication. Beijing: Foreign Language Teaching and Research Press.

LIU, R. Q. (1996). English teaching in the 21th century-An investigation of Great Briton. Foreign Language Teaching and Research, 2, 69-71.

XU, J. (2000). A review of acculturation. Foreign Language Teaching, 21(3), 9-13. 